\title{
Заицита растений
}

\section{УДК 632.4.01/08 \\ РАЗНООБРАЗИЕ ФЕНОТИПОВ ВИРУЛЕНТНОСТИ ПОПУЛЯЦИИ Риccinia triticina В РАЗЛИЧНЫХ АГРОКЛИМАТИЧЕСКИХ ЗОНАХ СЕВЕРНОГО КАВКАЗА*}

\author{
Г.В. Волкова, доктор биологических наук, \\ О.А. Кудинова, кандидат биологических наук, О.Ф. Ваганова \\ Всероссийский научно-исследовательский институт биологической защиты растений, \\ 350039, Краснодар, 39 \\ E-mail: galvol@bpp.yandex.ru
}

\begin{abstract}
Проанализирован фенотипический состав северокавказской популяции возбудителя бурой рэсавчины пиеницы (Риссіпіа triticina Еrikks.) в различных агроклиматических зонах региона в 2016-2018 г2. Изучено 233 монопустульных изолята, из которых идентифицировано 212 фенотипов вирулентности. Во все годы исследований установлен высокий уровень разнообразия популяции (индекс ШІенона (Sh) составил 0,92-0,99). В 2016 г. доминировал фенотип PHRS, который был идентифицирован в южкной предгорной, западной приазовской и восточной степной агроклиматических зонах. В популяции этого года преобладали фенотипы с высоким и средним числом аллелей вирулентности. В 2017 2. наиболее представлены фенотипы DCRL, LBLL (западная приазовская зона) и РСQВ (северная зона). Авирулентный фенотип ВВВВ был обцим для популяций 2016-2018 г2. В 2016 г. впервые обнаружен фенотип с вирулентностью к линии, несущей ген Lr9 (TLGS). В 2017 и 2018 z2. в популяциях гриба выявлены фенотипы, вирулентные к линии с геном Lr24 (РКTT, SFGQ, CFPQ, TKTS, MKTT, LKSR). Установлен высокий уровень различий популяций по фенотипическому составу между годами исследований (индекс Роджерса (R) составил 0,96 -0,99).
\end{abstract}

\section{DIVERSITY OF VIRULENCE PHENOTYPES OF Puccinia triticina IN DIFFERENT AGROCLIMATIC ZONES OF THE NORTH CAUCASUS}

\author{
Volkova G.V., Kudinova O.A., Vaganova O.F. \\ All-Russian Scientific Research Institute of Biological Plant Protection, \\ 350039, Krasnodar, 39 \\ E-mail: galvol@bpp.yandex.ru
}

\begin{abstract}
The phenotypic composition of the North Caucasian population of wheat leaf rust pathogen (Puccinia triticina Erikks.) in various agro-climatic zones of the region in 2016-2018 is analyzed. 233 single pustule isolates were studied, of which 212 virulence phenotypes were identified. In all the years of research, a high level of population diversity was established (the Shannon index (Sh) was 0.92-0.99). The dominant phenotype in 2016 was the PHRS phenotype, which was identified in the southern foothill, western Azov and eastern steppe agro-climatic zones. In the population of 2016, phenotypes with a high and medium number of virulence genes prevailed. In 2017, the most represented are the phenotypes of DCRL, LBLL (Western Azov zone) and PCOB (Northern zone). Avirulent phenotype BBBB was common for populations of 2016-2018. In 2016, a phenotype with virulence to Lr9 (TLGS) was first detected. In 2017 and 2018, phenotypes virulent to the Lr24 gene (PKTT, SFGQ, CFPQ, TKTS, MKTT, LKSR) were detected in the populations of the fungus. A high level of population differences in phenotypic composition between the years of research was established (Rogers index (R) was $0.96-0.99)$.
\end{abstract}

Ключевые слова: озимая пшеница, бурая ржавчина, фенотип вирулентности, разнообразие, агроклиматические зоHbl

Северо-Кавказский регион - основной по возделыванию озимой пшеницы, посевная площадь которой составляет $55 \%$ всех посевов озимых в Российской Федерации. Эта культура подвержена ряду опасных фитопатогенов, среди которых возбудитель бурой ржавчины (Puccinia triticina Erikks.) - один из вредоносных и распространенных [1]. В связи с благоприятным для развития патогена климатом и большими площадями выращивания растения-хозяина бурая ржавчина остается значимой болезнью пшеницы на Северном Кавказе [2]. Поэтому разработка эффективных методов защиты от вредоносного патогена особенно актуальна для данного региона. Традиционно на больших площадях возделывания болезнь контролируется посредством применения эффективных фунгицидов. Но усиливающаяся экологизация сельскохозяйственного производства требует безопасных методов защиты пшеницы от бурой ржавчины, таких как возделывание сортов, защищенных генами устойчивости к болезни [3]. Известно,
Key words: winter wheat, leaf rust, virulence phenotype, diversity, agro-climatic zones

что для правильного и эффективного использования потенциала различных сортов необходима научно обоснованная стратегия сорторазмещения по аэроландшафтным нишам и правильной сортосмены [4]. Важны также знания о динамике фенотипического состава популяции патогена в различных агроклиматических зонах, различающихся по тепло- и влагообеспеченности. Поэтому ежегодные исследования вирулентности и фенотипического состава популяции бурой ржавчины проводят в различных регионах мира [5-7]. В России подобные работы выполняют в основных зернопроизводящих регионах. Изучают вирулентность гриба в Нижнем Поволжье, на Урале, в Западно-Сибирском, Северо-Западном и Центральном регионах [8-12]. Так, в Северо-Кавказском регионе описана вирулентность популяции возбудителя бурой ржавчины в различных агроклиматических зонах в 2006-2015 гг. [2,13,14].

Целью настоящей работы был анализ фенотипического состава северокавказской популяции P. triticina в

\footnotetext{
* Исследования выполнены согласно Государственному заданию № 075-00376-19-00 Министерства науки и высшего образования РФ в рамках НИР по теме № 0686-2019-0008.
} 
2016-2018 гг. в пяти агроклиматических зонах, а также выявление общих и доминирующих фенотипов, оценка фенотипического разнообразия и уровня различий популяции гриба по годам исследований.

Методика. Для сбора инфекционного материала ежегодно (в фазе молочно-восковой спелости зерна) выполняли маршрутные обследования селекционных и производственных посевов озимой пшеницы в пяти агроклиматических зонах региона, различающихся по тепло- и влагообеспеченности (рис.). Листья, пораженные болезнью, были собраны на посевах пшеницы в каждой агроклиматической зоне и использованы для выделения монопустульных изолятов гриба. Получение монопустульных изолятов, их размножение проводили по существующим методикам [14].

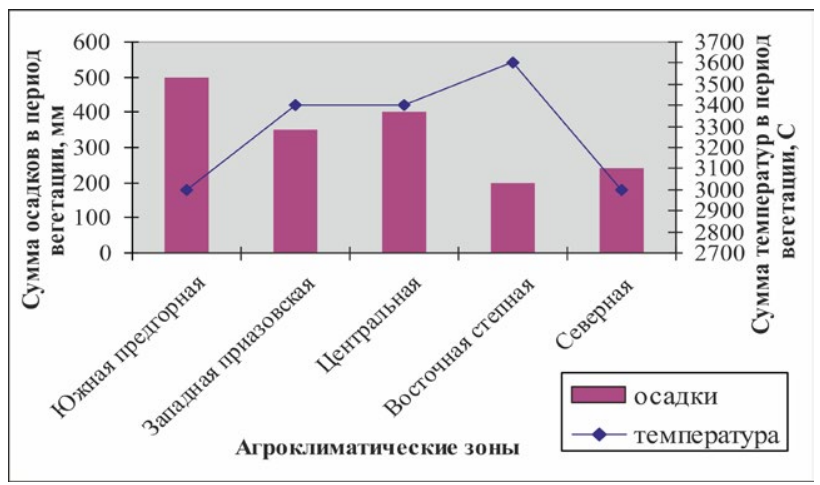

Характеристика агроклиматических зон Северного Кавказа

по тепло- и влагообеспеченности [20].

Для анализа вирулентности изолятов P. triticina использовали 16 близкоизогенных линий Thatcher с генами Lr: 1, 2a, 2c, 3, 9, 16, 24, 26, 3ka, 11, 17, 30, $B, 10,14 a, 18$. Растения каждой линии выращивали в вазонах (50 мл) на гидропонике с применением питательного раствора Кнопа [15]. В возрасте одного листа их инокулировали суспензией спор монопустульного изолята. После влажной камеры растения содержали при $18-20^{\circ} \mathrm{C}$, интенсивности освещения до 15 тыс. лк и влажности воздуха 60-70\%. На 10-14-й день по шкале Mains и Jackson [16] регистрировали инфекционные типы (IT) как высокие (IT от 3 до 4), так и низкие (IT от 0 до 2).

Буквенное обозначение фенотипов проводили согласно североамериканской номенклатуре [17]. Разнообразие популяции по фенотипическому составу оценивали по индексу Shannon [18]. Различия между популяциями по фенотипам вирулентности оценивали с помощью индекса Роджерса [19]:

$$
\mathrm{H}_{\mathrm{r}}=1 / 2 \sum(p i 1-p i 2) \text {, }
$$

где $p i 1$ - частота $i$-го фенотипа в первой популяции; pi 2 - частота і-го фенотипа во второй популяции.

Результаты и обсуждение. В условиях 2016 г. складывающиеся погодные условия благоприятствовали развитию фитопатогенов на озимых зерновых колосовых культурах. Бурая ржавчина пшеницы была отмечена во всех пяти агроклиматических зонах региона. В вегетационном сезоне 2017 г. условия ранневесеннего периода были благоприятными для роста и развития озимых. Однако частые дожди в июне и пониженный температурный режим задерживали созревание пше- ницы и создавали условия для развития болезней. Бурая ржавчина была выявлена в четырех агроклиматических зонах (кроме восточной степной) с максимальным развитием в центральной зоне (6,8 \%). 2018 г. был неблагоприятным для развития фитопатогенов. На фоне аномально жаркой погоды апреля-июня наблюдали значительный дефицит осадков (20-30\% нормы), что способствовало развитию почвенной и атмосферной засухи, которая к концу июня достигла критериев опасного явления. Относительная влажность воздуха снижалась до 45-55 \%, что на 15-20\% ниже нормы. В связи с этим бурая ржавчина была отмечена в трех агроклиматических зонах - южной предгорной, западной приазовской и центральной (с развитием до 1-2 \%).

В 2016-2018 гг. изучено 233 монопустульных изолята P. triticina, из которых идентифицировано 212 фенотипов вирулентности. Как и в предыдущие годы [13, 14], популяция возбудителя бурой ржавчины в регионе продолжает оставаться высокоразнообразной (табл. 1). При этом максимальное разнообразие по фенотипическому составу выявлено в популяции 2017 г. Несмотря на неблагоприятные условия вегетационного сезона 2018 г., разнообразие популяции P. triticina сохранилось на высоком уровне.

Табл. 1. Характеристика разнообразия популяции P. triticina на Северном Кавказе по фенотипическому составу

\begin{tabular}{|l|c|c|c|}
\hline Характеристика популяции & 2016 г. & 2017 г. & 2018 г. \\
\hline Число изолятов, шт. & 90 & 82 & 61 \\
Число фенотипов, шт. & 76 & 79 & 57 \\
$\begin{array}{l}\text { Число уникальных феноти- } \\
\text { пов, шт. }\end{array}$ & 70 & 76 & 54 \\
Индекс разнообразия, Sh & 0,92 & 0,99 & 0,97 \\
\hline
\end{tabular}

Фенотипы вирулентности в пяти агроклиматических зонах приведены в табл. 2, формулы вирулентности (неэффективные гены) доминирующих и повторяющихся фенотипов - в табл. 3. В 2016 г. из 90 монопустульных изолятов было идентифицировано 76 фенотипов. Фенотипы PHRS, THRS, PGRS, PBMJ, PBRQ, BBBB, MHTT были повторяющимися, остальные - уникальными. В 2016 г. доминировал фенотип PHRS, который был идентифицирован в южной предгорной, западной приазовской и восточной степной агроклиматических зонах. Фенотип THRS встречался в центральной и восточной степной зонах, PGRS - в западной приазовской и восточной степной, PBRQ - в южной предгорной зоне. Эти фенотипы содержат среднее число аллелей вирулентности. Кроме вирулентных, в 2016 г. повторялись также авирулентные (BBBB) и слабовирулентные (PBMJ) фенотипы. В целом в популяции 2016 г. преобладали фенотипы с высоким и средним числом аллелей вирулентности.

В 2017 г. доминировали фенотипы DCRL, LBLL (западная приазовская зона) и PCQB (северная зона). Авирулентный фенотип ВВВВ обнаружен, как и в 2016 г., в северной зоне с недостаточной тепло- и влагообеспеченностью (рис.). В 2017 и 2018 гг. в южной предгорной зоне преобладали фенотипы группы В (BВBВ, BBBL, BBDT, BHDT, BHLQ, BBBG, BBCB, FBBB, KBBD, QBLL, QBBB), содержащие минимальное число аллелей вирулентности. Это может быть связано как с биотическими (сортовой состав), так и абиотическими 
Табл. 2. Фенотипический состав северокавказской популяции P. triticina в различных агроклиматических зонах, 2016-2018 гг.

\begin{tabular}{|c|c|c|c|}
\hline Год & $\begin{array}{c}\text { Агрокли- } \\
\text { матиче- } \\
\text { ская зона }\end{array}$ & \begin{tabular}{|c|} 
Число \\
изо- \\
лятов, \\
шт. \\
\end{tabular} & Фенотипы \\
\hline \multirow[t]{5}{*}{2016} & $\begin{array}{l}\text { Южная } \\
\text { предгор- } \\
\text { ная }\end{array}$ & 17 & $\begin{array}{l}\text { MHTT*, TLGS, THJJ, THTT, PHRS, } \\
\text { PGRS, PBQG, PGCT, PRGS, PBRQ, } \\
\text { RHHS, RCTT, RGRS, NBCP, FGNQ }\end{array}$ \\
\hline & $\begin{array}{l}\text { Западная } \\
\text { приазов- } \\
\text { ская }\end{array}$ & 11 & $\begin{array}{l}\text { PHRS, PGRS, PCQJ, SBMN, CBMQ, } \\
\text { FHMG, DBCL, PBMJ, LBRL }\end{array}$ \\
\hline & $\begin{array}{c}\text { Централь- } \\
\text { ная }\end{array}$ & 28 & $\begin{array}{l}\text { MCPB, MCKJ, TGPD, THRS, THTS, } \\
\text { THRR, THTQ, TCTS, PDLG, PBSS, } \\
\text { PQBB, PCTT, PCTS, PHTS, PHSJ, } \\
\text { PHRS, BBBB, BCCB, LHLH, CGPD, } \\
\text { NHKL, NCCJ, NHTL, FGTD, FGTG, } \\
\text { QHPH, QGRQ, GBRS }\end{array}$ \\
\hline & $\begin{array}{l}\text { Восточная } \\
\text { степная }\end{array}$ & 18 & $\begin{array}{l}\text { MHRS, MCRQ, THRS, THRQ, TBQS, } \\
\text { PHRS, PHMQ, PHRQ, PCQQ, PHRN, } \\
\text { PGRS, LBBL, FHRG, FCMJ, FHHS, } \\
\text { FCMJ, }\end{array}$ \\
\hline & Северная & 16 & $\begin{array}{l}\text { MBGG, MBGL, PHRT, PGTN, PGKL, } \\
\text { PGRL, BBBB, BBBL, LBCL, NHSJ, } \\
\text { FHTQ, KBML, HHTG, HHRN, DBNB, } \\
\text { TCCS }\end{array}$ \\
\hline \multirow[t]{4}{*}{2017} & $\begin{array}{l}\text { Южная } \\
\text { предгор- } \\
\text { ная }\end{array}$ & 24 & $\begin{array}{c}\text { MBLS, MBBG, TBBD, TBBL, TBBB, } \\
\text { BBBG, BBCB, RBHB, RBHB, CBCL, } \\
\text { CBLG, NCRQ, NGBD, NBGM, NBCB, } \\
\text { FGBG, FBHB, FBBB, KBBD, QBLL, } \\
\text { QBBB, HBBG, HBCN, GBBL }\end{array}$ \\
\hline & $\begin{array}{l}\text { Западная } \\
\text { приазов- } \\
\text { ская }\end{array}$ & 26 & $\begin{array}{c}\text { MBRB, MBFB, PHMJ, PGDQ, PGDQ, } \\
\text { PCRC, PGMJ, BCBM, LBLL, LDBD, } \\
\text { CGRP, NBHN, NHGR, FGPL, FBQB, } \\
\text { FBTB, FBRG, HCMQ, DBRG, DCRL, } \\
\text { DGBL, DGBG, DCBG, DGNL }\end{array}$ \\
\hline & $\begin{array}{c}\text { Централь- } \\
\text { ная }\end{array}$ & 17 & $\begin{array}{c}\text { MBSG, TGRJ, TBHS, PBCB, PGTQ, } \\
\text { PHRQ, PGRL, RGRN, RHTG, LCLN, } \\
\text { NHRH, FCTS, FGTK, FCTG, FBMG, } \\
\text { GGRS, DCTQ }\end{array}$ \\
\hline & Северная & 14 & $\begin{array}{l}\text { THQT, TCQQ, PCQB, BBBB, SHBL, } \\
\text { LCLB, CCGB, CBLG, NGBB, FHGB, } \\
\text { FGLB, FBLB, JBLB }\end{array}$ \\
\hline \multirow[t]{3}{*}{2018} & $\begin{array}{l}\text { Южная } \\
\text { предгор- } \\
\text { ная }\end{array}$ & 18 & $\begin{array}{l}\text { MJTM, MHJP, MGLS, TKTS, PBJS, } \\
\text { PKPQ, BHLQ, BBBB, BBDT, BBBL, } \\
\text { BHDT, LHSC, LHRQ, LGTR, LGRT, } \\
\text { CHMT, NHPT }\end{array}$ \\
\hline & $\begin{array}{l}\text { Западная } \\
\text { приазов- } \\
\text { ская }\end{array}$ & 20 & $\begin{array}{l}\text { MHTT, MHMH, MDTT, MBTL, } \\
\text { MGTP, MBTR, MJPT, MKTT, MHPT, } \\
\text { MCLK, PHTP, PKTT, RHHT, LHTT, } \\
\text { LKSR, CGTS }\end{array}$ \\
\hline & $\begin{array}{c}\text { Централь- } \\
\text { ная }\end{array}$ & 21 & $\begin{array}{l}\text { MHTR, MMRG, MHTN, MHST, TGPT, } \\
\text { PCTD, PHQL, PHTD, PHTQ, PHTG, } \\
\text { PHTK, PCTQ, PHTT, PCPR, PCTL, } \\
\text { KGHS, BCDR, SHTT, SFGQ, CFPQ, } \\
\text { NCSN }\end{array}$ \\
\hline
\end{tabular}

(пониженная теплообеспеченность зоны) факторами.

В западной приазовской и центральной зоне преобладали фенотипы с высоким содержанием аллелей вирулентности (MHTT, MDTT, SHTT, PHTT, PHTQ и др.). Из табл. 3 видно, что в 2018 г. повторяются фенотипы P. triticina, которые авирулентны (ВВВВ) или содержат большое число аллелей вирулентности (МНТТ, РКТТ). В 2017 и 2018 гг. в популяциях гриба отмечали фенотипы, вирулентные к линии с геном Lr24 (например, PKTT, SFGQ, CFPQ, TKTS, MKTT, LKSR). Одиночные изоляты, вирулентные к данной линии, были отмечены в северокавказской популяции и в предыдущие годы $[13,14]$. В 2016 г. впервые обнаружен фенотип с
Табл. 3. Вирулентность и частота (\%) повторяющихся фенотипов северокавказской популяции P. triticina, 2016-2018 гг.

\begin{tabular}{|c|c|c|c|c|}
\hline \multirow{2}{*}{$\begin{array}{l}\text { Фенотип } \\
\text { виру- } \\
\text { лентно- } \\
\text { сти }\end{array}$} & \multirow{2}{*}{$\begin{array}{c}\text { Вирулентность } \\
\text { (неэффективные } \\
\text { гены) }\end{array}$} & \multicolumn{3}{|c|}{ Шт./частота, \% } \\
\hline & & 2016 г. & 2017 г. & 2018 г. \\
\hline PHRS & $\begin{array}{c}1,2 \mathrm{c}, 3,16,26,3 \mathrm{ka} \\
11, \mathrm{~B}, 10,14 \mathrm{a}\end{array}$ & 9/9,9 & 0 & 0 \\
\hline THRS & $\begin{array}{l}1,2 \mathrm{a}, 2 \mathrm{c}, 3,16,26 \\
3 \mathrm{ka}, 11, \mathrm{~B}, 10,14 \mathrm{a}\end{array}$ & $2 / 2,2$ & 0 & 0 \\
\hline PGRS & $\begin{array}{c}1,2 \mathrm{c}, 3,16,3 \mathrm{ka}, 11 \\
\mathrm{~B}, 10,14 \mathrm{a}\end{array}$ & $3 / 3,3$ & 0 & 0 \\
\hline PHRQ & $\begin{array}{c}1,2 \mathrm{c}, 3,16,26,3 \mathrm{ka} \\
11, \mathrm{~B}, 10\end{array}$ & $1 / 1,1$ & $1 / 1,2$ & 0 \\
\hline PGRL & $\begin{array}{c}1,2 \mathrm{c}, 3,16,3 \mathrm{ka}, \\
11, \mathrm{~B}\end{array}$ & $1 / 1,1$ & $1 / 1,2$ & 0 \\
\hline PBMJ & $1,2 \mathrm{c}, 3,11,10,14 \mathrm{a}$ & $2 / 2,2$ & 0 & 0 \\
\hline PBRQ & $\begin{array}{c}1,2 \mathrm{c}, 3,16,26,3 \mathrm{ka}, \\
11, \mathrm{~B}, 10\end{array}$ & $2 / 2,2$ & 0 & 0 \\
\hline $\mathrm{BBBB}$ & 0 & $2 / 2,2$ & $1 / 1,2$ & $2 / 3,3$ \\
\hline DCRL & $2 \mathrm{c}, 26,3 \mathrm{ka}, 11, \mathrm{~B}$ & 0 & $2 / 2,4$ & 0 \\
\hline LBLL & $1,3 \mathrm{ka}, \mathrm{B}$ & 0 & $2 / 2,4$ & 0 \\
\hline PCQB & $1,2 \mathrm{c}, 3,26,3 \mathrm{ka}, 11$ & 0 & $2 / 2,4$ & 0 \\
\hline MHTT & $\begin{array}{c}1,3,16,26,3 \mathrm{ka}, \\
11,17,30, \mathrm{~B}, 10 \\
14 \mathrm{a}, 18\end{array}$ & $2 / 2,2$ & 0 & $1 / 1,6$ \\
\hline PKTT & $\begin{array}{c}1,2 \mathrm{c}, 3,16,24,26 \\
3 \mathrm{ka}, 11,17,30, \mathrm{~B} \\
\quad 10,14 \mathrm{a}, 18\end{array}$ & 0 & 0 & $3 / 4,9$ \\
\hline
\end{tabular}

вирулентностью к линии, содержащей $\operatorname{Lr} 9$ (TLGS). В предыдущие годы таковых не наблюдалось [13], хотя в других регионах этот ген уже потерял эффективность $[9,11]$. В целом различия по фенотипическому составу гриба между годами, оцениваемые с помощью индекса Роджерса (R), существенные для каждой пары сравниваемых популяций (для 2016 и 2017 гг. $\mathrm{R}=0,96,2017$ и 2018 гг. - 0,97, 2016 и 2018 гг. - 0,99).

Таким образом, в 2016-2018 гг. проведен мониторинг фенотипического состава популяции $P$. triticina в различных агроклиматических зонах Северного Кавказа. Из проанализированных 233 монопустульных изолята гриба идентифицировано 212 фенотипов. Выявлены повторяющиеся фенотипы в каждой агроклиматической зоне. Впервые обнаружен фенотип с вирулентностью к линии, содержащей $\operatorname{Lr} 9$ (TLGS). Установлен высокий уровень фенотипического разнообразия северокавказской популяции гриба $(\mathrm{Sh}=0,92-$ $0,99)$, а также существенный уровень различий популяции $P$. triticina по фенотипическому составу между годами исследований $(\mathrm{R}=0,96-0,99)$.

\section{Литература}

1. Kolmer, J.A., Hughes, M.E. Physiologic specialization of Puccinia triticina on wheat in the United States in 2012. // Plant Disease. - 2014. - V. 98. - P. 1145-1150. http://dx.doi.org/10.1094/PDIS-12-13-1267-SR

2. Волкова Г.В., Анпилогова Л.К., Ваганова О.Ф., Авдеева Ю.В. Характеристика популячии возбудите- 
ля бурой ржавчины пшениць по вирулентности в пяти агроклиматических зонах Северного Кавказа // Докладь Российской академии сельскохозяйственных наук. - 2011. - №4. - C. 31-33.

3. Гультяева Е.И., Шаманин В.П., Шайдаюк Е.Л., Потоцкая И.В., Пожерукова В. Е., Кузьмин О. Г. Фенотипический состав Pисcinia triticina на образизах мягкой пшеницы в Омской области в 2016 г. // Вестник НГАУ. - 2017. - № 2. (43). - С. 16-23.

4. Зазимко М.И., Фетисов Д.П., Егоров С.С., Мальххна A. Н. Роль сорта в защите озимой пшениць // Защита и карантин растений. - 2008. - №6. - C. 11-13.

5. Kolmer J.A., Hughes M.E. Physiologic specialization of Puccinia triticina on wheat in the United States in 2016 // Plant disease. - 2018. - V. 102. - №6, - P. 10661071. https://doi.org/10.1094/PDI-11-17-1701-SR

6. Bhardwaj S.C., Gangwar O.P., Prasad P., Kumar S., Khan H., Gupta N. Physiologic specialization and shift in pathotypes on wheat in Indian subcontinent during 2013-2016 // Indian Phytopathology. - 2019. - V. 72. P. 23. https://doi.org/10.1007/s42360-018-00110-9

7. Liu T.G., Chen W.Q. Race and virulence dynamics of Puccinia triticina in China during 2002-2006 / /Plant Disease. - 2012. - V. 96. - P. 1601-1607. https://doi. org/10.1094/PDIS-06-10-0460-RE

8. Тырышкин Л.Г., Захаров В. Г., Сюков В. В. Сравнительная характеристика вирулентности Puсcinia recondita Rob. ex Desm. syn.: Puccinia triticina Erikss. в среднем Поволжье // Вавиловский журнал генетики и селекиии. - 2014. - 18(2). - С. 373-377.

9. Тюнин В.А., Шрейдер Е.Р., Гультяева Е.И., Шайдаюк Е.Л. Вирулентность возбудителя бурой ржавчины пшеницы на Южном Урале // Вестник защииты растений. - 2018. - 1(95). - C. 16-20.

10. Коваленко Е.Д., Жемчужина А.И., Киселева М.И., Коломиеч Т.М., Щербик А.А. Стратегия селекиии пшеницы на устойчивость к ржавчинным заболеваниям // Защита и карантин растений. - 2012. № 9. - C. 19-22.
11. Гультяева Е.И., Косман Е., Дмитриев А.П., Баранова O.A. Структура популяичй Pисcinia triticina no вирулентности и ДНК-маркерам в Северо-Западном регионе РФ в 2007 году // Микология и фитопатология. - 2011. - 45 (1). - С. 70-81.

12. Мешкова Л.В., Плотникова Л.Я., Штубей Т.Ю., Алексеева О.А., Отт А. А. Перспективные гены и генные комбинации для защиты мягкой пшениџы от бурой ржавчины в Западной Сибири. // Вестник Россельхозакадемии. - 2011. - №2. - С. 50-52.

13. Волкова Г.В., Анпилогова Л.К., Полушин П.А., Ваганова О. Ф. Характеристика популячии бурой ржавчинь по вирулентности в Северо-Кавказском регионе //Вестник Российской академии сельскохозяйственных наук. - 2013. - № 2. - C. 45-48.

14. Волкова Г.В., Кудинова О.А., Гладкова Е В., Ваганова О.Ф., Данилова А.В., Матвеева И.П. Вирулентность популяций возбудителей ржавчины зерновых колосовых культур (учебное пособие). - Краснодар, 2018. -38 c.

15. Смирнова Л.А., Алексеева Т.П. Усовершенствованный метод выращиивания всходов зерновых культур для иммунологических исследований // Селекщия $u$ семеноводство. - 1988. - №4. - C. 25-27.

16. Mains E. B., Jackson H. C. Physiologic specialization in the leaf rust of wheat: Puccinia triticina Erikss // Phytopathology. - 1926. - V. 16(1). - P. 89-120.

17. Long D.L., Kolmer J.A. A North American System of Nomenclature for Puccinia triticina. // Phytopathology. 1989. - V. 79. - P. 525-529.

18. Kolmer J. A., Long D. L., Kosman E., Hughes M. E. Physiologic specialization of Puccinia triticina on wheat in the United States in 2001 // Plant Disease. 2003. - V. 87. - P. 859-866.

19. Rogers J. S. Measures of genetic similarity and genetic distance. Studies in Genetics. University of Texas. Austin., 1972. - P.143-145.

20. Батова В. М. Агроклиматические ресурсы Северного Кавказа. - Л., 1966. - С. 132-143.

Поступила в редакцию 22.04.19 Принята к публикации 01.07.19 